Western University

Scholarship@Western

FIMS Presentations

Information \& Media Studies (FIMS) Faculty

2010

\title{
Methodological Strategies for Studying Documentary Planning Work.
}

Pamela J. McKenzie

University of Western Ontario, pmckenzi@uwo.ca

Elizabeth Davies

Lola Wong

The University of Western Ontario, lwong227@uwo.ca

Follow this and additional works at: https://ir.lib.uwo.ca/fimspres

Part of the Communication Commons, and the Library and Information Science Commons

Citation of this paper:

McKenzie, Pamela J.; Davies, Elizabeth; and Wong, Lola, "Methodological Strategies for Studying Documentary Planning Work." (2010). FIMS Presentations. 30.

https://ir.lib.uwo.ca/fimspres/30 
Pamela J. McKenzie

Faculty of Information and Media Studies, UWO, London, Ontario

Elisabeth Davies,

School of Information Management, Dalhousie University, Halifax, Nova Scotia, Lola Wong

Faculty of Information and Media Studies, UWO, London, Ontario

\title{
Methodological strategies for studying documentary planning work
}

\begin{abstract}
This paper reports on the pilot testing of data collection strategies for a study of the complex and idiosyncratic document work involved in everyday life planning and time management. We describe two iterations of two data collection strategies, in-depth semistructured interviews and photography of individual documents and document collections.
\end{abstract}

Résumé : Cette communication présente un projet pilote de stratégies de collecte de données pour l'étude du travail documentaire complexe et idiosyncratique nécessaire à la planification et à la gestion du temps au quotidien. Seront présentées deux itérations de deux stratégies de collecte de données : les entrevues en profondeur semi-structurées et la photographie de documents individuels et de collections de documents.

\section{Introduction}

The creation and use of documents has long been an interest in library and information science (e.g., Case, 1986). Recent research in this area offers new perspectives on personal information management (PIM) in everyday and workplace settings (e.g., Jones, 2008; Trace, 2007; Shankar, 2009). Although individuals may develop idiosyncratic and profoundly personal systems for keeping track of their immediate environments (Shankar, 2009; Trace 2007), individual recordkeeping both draws its conventions from and contributes to the persistence of larger infrastructures (Star, 1999). Trace (2007) uses the term document work to describe the situated understanding of how documents are and ought to be produced and used in a particular setting, and how they reflect the social nature of the world around them. Knowledge of how to read, write, search, and use documents appropriately is constituted and evaluated through the practices of a specific community.

Trace (2007) argues that the study of document work involves studying social meanings produced: through conversation, through other methods such as textual representations, and through actions that occur, or do not occur, around text. She observes that document work is challenging to study, first because of its very invisibility to the people who do it, and second because it requires little talk that might illuminate the role documents play. This paper reports on the pilot testing of a set of data collection strategies for a study of the document work involved in everyday life planning and time management.

Previous studies provide the context for understanding the particular methodological challenges of studying the ways that people use documents to plan and manage time in everyday life (e.g., Beech et al., 2004; Grimes and Brush, 2008; Nippert-Eng, 1996; Sellen et al., 2004). Organizational systems of multiple tools are common (Tungare et al., 2008), and paper persists even in highly computerized environments because of its 
flexibility (e.g., Tomitsch et al., 2006). Individuals and families place artifacts in contextual locations that exploit family routines to ensure that the right person sees the right artifact at the right time (Crabtree et al., 2003). Taylor and Swan (2005) argued that collections of heterogeneous artifacts constitute artful, idiosyncratic organizing systems that are constantly evolving to meet local needs and that both come out of and create families' routines.

The challenge for data collection, then, is that relevant tools are likely to be multiple (and possibly in multiple formats) and physically distributed in ways that are important to their use. Further, the use of some tools is likely to be so ingrained that the tool user may not even remember or comment on it unless reminded. This means that effective data collection will need to combine methods such as semi-structured interviews to identify situated tools and collections of tools (Shankar, 2009; Grimes and Brush, 2008; Hartel, 2005; Neustaedter et al., 2009; Taylor and Swan, 2005; and Tungare et al., 2008; Beech et al., 2004), and observation and documentation of the tools participants create and use (e.g., Case, 1986; Hartel, 2005; Kalms, 2008; Shankar, 2009).

\section{Methods}

This paper documents on our ongoing process of developing, pretesting, and refining two major data collection methods: in-depth semi-structured interviews and the development of guides to help us identify and photograph relevant tools. In developing our methods we have relied on previous work including:

- Kalms’ (2008) checklist of “typical information items” commonly found in households.

- Beech et al's (2004) three-step process in which they asked participants to walk them step by step through the events of the previous day, went over the resulting list to verify details, and then used the list as a framework for talking about the tools that enabled each event to be organized.

- Trace's (2007) recommendation that such data collection include questions that help to identify the widely taken-for-granted norms and infrastuctures that shape the everyday practices of recordkeeping. For example, questions on breakdowns (Star, 1999), cues or signals through which people learn what behaviour is acceptable, and violations of acceptable behaviour.

- Hartel's advice on developing photographic inventories that can both characterize organizational systems and serve as a framework for asking questions about them and their use. Hartel (2005) suggests that the gathering of visual data proceed from unstructured to structured. She advises using the first data collection sessions to view the setting broadly and to experiment with ways to visually capture the subjects of interest. From here, the researcher may create a "shooting guide" that structures the subsequent field experience. The shooting guide will define what will be photographed, a shooting order, and number of photographs. Hartel's guidelines were developed for collections of documents that largely consist of items authored by someone other than the collector. The collections of resources of interest to us are likely to be more haphazard and include more documents created by the collector him- or herself. 


\section{Findings}

We take an iterative grounded theory approach (Strauss and Corbin, 1990) to analyse the data collected and researchers' field notes, memos, meeting minutes, draft interview guides and shooting guides with a view to improving data collection methods. To date we have completed two iterations of data collection at two sites. McKenzie and Wong conducted two interviews in Ontario and Davies conducted two interviews in Nova Scotia. In our paper we reflect on the process of developing and refining data collection strategies, and we discuss:

- the challenges of developing an appropriate initial question that is comprehensible to the interviewee;

- the relative merits and challenges of employing a time-line interview technique;

- the differential challenges of managing the interviewing and photography processes with a single researcher versus a team of two;

- strategies for encouraging participants to think about their use of time management tools that may not be physically present in the interview space;

- strategies for systematically observing tools that are physically present in the interview space, even when these are not mentioned by the participant;

- equipment considerations: identifying the appropriate settings for audio recording and for photographing of individual documents and document collections;

- the challenges of developing templates for photographic inventories;

- the processes developed by the research team to develop data collection collaboratively;

- the implications of these data collection decisions on data analysis and the refinement of data collection based on initial analyses.

We conclude with reflections on the advantages and disadvantages of our move away from structured checklists and guides to a more open-ended interview strategy, and we consider the challenges of proceeding spatially (e.g., by asking systematically about all of the tools in a specific space) or thematically (e.g., by asking about a specific event and all of the tools used to manage it).

\section{References}

Case, Donald Owen. 1986. Collection and organization of written information by social scientists and humanists: a review and exploratory study. Journal of Information Science 12: 97-104.

Crabtree, Andy, Terry Hemmings, Tom Rodden, and John Mariani. 2003. Informing the development of calendar systems for domestic use. Proceedings of the 8th European Conference on Computer Supported Cooperative Work, eds E. H. Karsten G. Fitzpatrick P. Dourish and K. Schmidt K. Kuutti, 119-38Amsterdam: Kluwer Academic Publishers.

Grimes, Andrea, and A. J. Brush. 2008. Life scheduling to support multiple social roles. Proceeding of the twenty-sixth annual SIGCHI conference on Human factors in computing systems table of contents, 821-24 New York: ACM.

Hartel, Jenna. 2005. Pictures worth a thousand words: a visual approach to the study of 
libraries in the home. Unpublished; which winner of the Dialog/ALISE Methodology Paper Competition 2006.

Jones, William. 2008. Keeping found things found: the study and practice of personal information management. Burlington, MA: Morgan Kaufman Publishers.

Kalms, Bryan. 2008. Household information practices: how and why householders process and manage information. Information Research 13, no. 1: paper 339.

Neustaedter, Carman, A. J. Bernheim Brush, and Saul Greenberg. 2009. “The calendar is crucial”: coordination and awareness through the family calendar. ACM Transactions on Computer-Human Interaction 16, no. 1: Article \#6: 1-48.

Nippert-Eng, Christena. 1996. Calendars and keys: the classification of "home" and “work”. Sociological Forum 11, no. 3: 563-82.

Sellen, Abigail, Jenny Hyams, and Rachel Eardley. 2004. The everyday problems of working parents: implications for new technologies, HPL-2004-37. Mobile and Media Systems Laboratory, HP Laboratories Bristol, http://research.microsoft.com/enus/um/people/asellen/publications/everyday\%20problems\%2004.pdf.

Shankar, Kalpana. 2009. Ambiguity and legitimate peripheral participation in the creation of scientific documents. Journal of Documentation 65, no. 1: 151-65.

Star, Susan Leigh. 1999. The ethnography of infrastructure. American Behavioral Scientist 43, no. 3: 377-391.

Strauss, Anselm and Juliet Corbin. 1990. Basics of qualitative research: grounded theory procedures and techniques. Newbury Park, CA: Sage.

Taylor, Alex S., and Laurel Swan. 2005. Artful systems in the home. CHI 2005 papers.

Trace, Ciaran B. 2007. Information creation and the notion of membership. Journal of Documentation 63, no. 1: 142-63.

Tomitsch, Martin, Thomas Grechenig, and Pia Wascher. 2006. Personal and private calendar interfaces support private patterns: diaries, relations, emotional expressions. NordiCHI '06: Proceedings of the 4th Nordic conference on Humancomputer interaction: changing roles. New York: ACM.

Tungare, Manas, Manuel Pérez-Quiñones, and Alyssa Sams. 2008. An exploratory study of personal calendar use, Computing Research Repository (CoRR) 0809.3447. 